\title{
PENGETAHUAN ORANGTUA TENTANG PENDIDIKAN SEKS PADA ANAK USIA DINI
}

\author{
Elisabeth Fransisca S.Sitio ${ }^{1}$, Sophia Oktavia B, ${ }^{2}$ Annisa Agesy S.P3 \\ Program Studi PG PAUD FKIP Universitas Palangka Raya \\ Jl. H. Timang Komplek Kampus Tunjung Nyaho Palangka Raya
}

\section{Email : ${ }^{1}$ elisabeth@fkip.upr.ac.id}

\begin{abstract}
ABSTRAK
Penelitian ini bertujuan untuk mengetahui pengetahuan orangtua tentang pendidikan seks pada anak usia dini. Penelitian ini menggunakan pendekatan kuantitatif deskriptif. Adapun subjek dari penelitian ini adalah 50 orangtua peserta didik di PAUD Terpadu. Hasil penelitian menunjukkan bahwa Pengetahuan orangtua di PAUD Terpadu tentang pendidikan seks pada anak usia dini masuk dalam kategori baik yaitu sebesar 78,34\%. Diperoleh 94\% orangtua dengan rentang usia 18-40 tahun memiliki pengetahuan baik mengenai pendidikan seks dimana $42 \%$ orangtua dengan latar pendidikan S1 dan 45\% dengan latar belakang pendidikan SMA. Hasil pada aspek orangtua mengetahui bahwa pentingnya mendampingi anak selama menonton televisi atau internet untuk meminimalisir pengaruh buruk seperti pelecehan seksual maupun penyimpangan perilaku seksual yaitu 100\%, dan diperoleh $42 \%$ orangtua mengetahui pentingnya mengajari anak sejak dini cara menjaga organ reproduksi.
\end{abstract}

\section{Kata kunci : Pengetahuan Orangtua, Pendidikan Seks, Anak Usia Dini}

\section{PENDAHULUAN}

Pendidikan seks merupakan bagian penting dalam mendidik anak, saat ini tidak lagi dipandang tabu memberikan informasi mengenai pendidikan seks. Namun tidak semua orangtua merasa nyaman untuk menyampaikan informasi atau menjawab pertanyaan anak mengenai pendidikan seks. Adanya pemahaman tentang seks hanya sebatas aktivitas mesum hingga hal-hal yang lebih intim menyebakan orangtua malu, sungan, untuk menyampaikan informasi mengenai seks pada anak selain itu masih ada orangtua yang belum memiliki pengetahuan komprehensif mengenai topik seksualitas. Orangtua hanya mengingatkan soal bahaya berhubungan seksual tanpa memberikan alasan-alasan yang lebih komprehensif. Pendidikan seks seharusnya menjadi kebutuhan 
penting, sehingga dapat mencegah terjadinya penyimpangan perilaku seksual, pelecehan seksual pada anak dan kehamilan tanpa pernikahan.

Fenomena kekerasan, pelecehan seksual dan penyimpangan seksual yang menimpa anak-anak di lingkungan sendiri salah satunya disebabkan kurangnya pendidikan seks pada anak. Menurut Yuliana (2016), seorang pemerhati perempuan dan anak dari Komunitas Jejer Wadon Solo, menyatakan bahwa maraknya kasus kekerasan seksual terhadap perempuan dan anak dipicu karena masih rendahnya pemahaman sex education atau pendidikan seks (https://solo.tribunnews.com/). Orangtua dalam hal ini, berperan penting dalam memberikan pendidikan seks pada anak, karena orangtua adalah orang yang paling dekat dengan anak (Fitrisari, 2016). Pendidikan seks adalah upaya pengajaran, penyadaran, dan pemberian informasi tentang masalah seksual. Informasi yang diberikan diantaranya adalah pengetahuan tentang fungsi organ reproduksi dengan menanamkan moral, etika, komitmen, dan agama, agar tidak terjadi penyalahgunaan organ reproduksi. Pendidikan seks dapat mulai dikenalkan pada anak sejak usia dini sesuai dengan tahap perkembangan kedewasaannya (Sani.2010).

Anak usia dini adalah anak yang baru dilahirkan sampai usia 6 tahun. Usia ini merupakan usia yang sangat menentukkan dalam pembentukkan karakter dan kepribadian anak. Usia dini merupakan usia ketika anak mengalami pertumbuhan dan pekembangan yang pesat, sering disebut dengan masa keemasan atau The Golden Age. Beberapa kajian oleh Bredecam dan Copple, Brener, serta Kellough tentang karakteristik anak usia dini diantaranya adalah: Anak bersikap unik, Anak mengekspesikan peilakunya secara relative spontan, Anak bersikap aktif dan enerjik, Anak itu egosentrisAnak memiliki rasa ingin tahu yang kuat dan antusias teradap banyak hal, Anak bersifat eksploratif dan berjiwa petualang, Anak umumnya kaya dengan fantasi, Anak masih mudah frustasi, Anak masih kuang pertimbangan dalam bertindak, Anak memiliki daya pehatian yang pendek, Masa anak merupakan masa belajar yang paling potsial dan Anak semakin menunjukkan minat terhadap teman. Oleh karena itu dengan semua keunikan masing-masing anak, orangtua harus menjadi fasilitator penyampaian informasi dan pemberian stimulus yang tepat bagi anak.

Kriswanto (2009) mengatakan bahwa pendidikan seks untuk anak harus dimulai sejak dini, bahkan sejak usia 0-5 tahun, selain itu melihat tahap perkembangan anak usia 3 - 6 tahun diantaranya adalah anak memiliki keingintahuannya sangat besar, mulai 
mempelajari adanya perbedaan jenis kelamin, senang memegangi genetali nya, mulai menirukan tindakan orangtuanya yang berjenis kelamin sama, bertanya tentang organ reproduksi yang berbeda, bertanya munculnya adik bayi, dll. Menghadapai kemungkinan pertanyaan anak, orangtua tidak boleh memarahi anak supaya tidak bertanya mengenai hal itu, karena ketika orangtua memarahi anak-anak maka dapat mengakibatkan anak mencari tahu sendiri dan akan menirukan tindakan-tindakan mneyimpang yang dilakukan atau meniru kata-kata kotor pada tayangan televisi yang dilihatnya (Hety, 2017). Oleh karena itu orangtua perlu memiliki pengetahuan mengenai pendidikan seks sehingga anak mengetahui informasi yang tepat dan berguna.

Keraf (dalam Salsabila 2017) menyatakan, pengetahuan selalu menuntut adanya kesadaran bahwa subjek itu sendiri tahu bahwa dia mengetahuinya. Pengetahuan pada tingkat tertentu mengandung unsur keyakinan dan keyakinan akan kebenaran dari pengetahuan tersebut, namun perlu adanya faktor pendukung dari hal tersebut. Notoatmodjo (2010) menuliskan pengetahuan orangtua dapat berperan sebagai edukator dan motivator untuk anak. Orangtua yang memiliki pengetahuan baik dapat melakukan pencegahan terhadap anak secara dini dengan cara memberitahukan hal-hal yang seharusnya dia lakukan dan yang seharusnya dihindari. Heyty (dalam Jurnal Hospital Majapahit.2017) menuliskan bahwa pengetahuan seseorang dapat dipengaruhi oleh faktor internal (usia, minat) dan faktor eksternal (pendidikan, pengalaman, informasi, keluarga, kebudayaan).

Pendidikan seks pada anak usia dini diantaranya adalah pengenalan peran jenis kelamin dan pengenalan anatomi tubuh secara sederhana, diajarkan menghargai tubuhnya sebagai barang berharga sehingga dapat menjauhkannya dari tindak pelecehan seksual, pendidikan seksual yang diberikan berkaitan dengan norma-norma yang berlaku di masyarakat, apa yang dilarang, apa yang dilazimkan dan bagaimana melakukannya tanpa melanggar aturan-aturan yang berlaku di masyarakat. Pendidikan seks adalah salah satu langkah atau upaya untuk mengurangi dan mencegah penyalahgunaan seks, khususnya untuk mencegah adanya dampak-dampak negatif yang tidak diharapkan seperti kehamilan yang tidak direncanakan, penyakit menular seksual, depresi dan tindak kekerasan seksual yang sering kali kerap terjadi pada anak (sarwono, 2005). 
Memberikan pendidikan seks pada anak usia dini tetap berpegang teguh dengan nilai-nilai moral dan agama, karena diharapkan akan membentuk individu yang dewasa dan bertanggung jawab, mampu berperilaku sesuai dengan gendernya dan bertanggung jawab terhadap apa yang dilakukan. Oleh sebab itu, pendidikan seks pada anak harus diberikan sedini mungkin oleh orang-orang terdekatnya terutama orangtua karena orangtua adalah orang yang paling sering berinteraksi dengan anak dan harapannya dapat membentengi anak dari pengaruh negatif yang ditimbulkan dari tontonan-tontotan yang tidak mendidik dan merusak otak anak (Muhsinin, 2017).

Menurut Abdullah Nashih Ulwan (dalam Madani, 2014) pendidikan seks adalah upaya pengajaran, penyadaran, dan penerangan tentang masalah-masalah seksual yang diberikan kepada anak sejak ia mengerti masalah-masalah yang berkenaan dengan seks, naluri, dan perkawinan. Sedangkan menurut D. Gunarsa (2008) Pendidikan seks merupakan cara pengajaran atau pendidikan yang dapat menolong muda - mudi untuk menghadapi masalah hidup yang bersumber pada dorongan seksual. Dengan demikian pendidikan seks ini bermaksud untuk menerangkan segala hal yang berhubungan dengan seks dan seksualitas dalam bentu yang wajar.

Menurut The Sex Information and Education Council The United States (SIECUS) (dalam Subiyanto, 1996) pendidikan seks mempunyai tujuan sebagai berikut:

1. Memberi pengetahuan yang memadai kepada siswa mengenai diri siswa sehubungan dengan kematangan fisik, mental dan emosional sehubungan dengan seks.

2. Mengurangi ketakutan dan kegelisahan sehubungan dengan terjadinya perkembangan serta penyesuaian seksual pada anak.

3. Mengembangkan sikap objektif dan penuh pengertian tentang seks.

4. Menanamkan pengertian tentang pentingnya nilai moral sebagai dasar mengambil keputusan.

5. Memberikan cukup pengetahuan tentang penyimpangan dan penyalahgunaan seks agar terhindar dari hal-hal yang membahayakan fisik dan mental.

Manfaat dari pendidikan seks menurut Dianawati (dalam Faisal, 2012) adalah masyarakat mendapatkan pandangan positif dan manfaat tentang informasi pendidikan seks, mengetahui akibat dan bahaya tentang perilaku penyimpangan seksual, dapat 
mengetahui tindakan yang menyimpang serta adanya upaya untuk menghidari hal tersebut, terutama jika hal ini terjadi pada anak, menghindari terjadinya hal-hal negatif yang diakibatkan dari pemahaman tentang pendidikan seks yang salah dan keliru.

Pendidikan seks yang dapat diberikan pada anak diantaranya adalah:

\section{Pengertian pendidikan seks}

Pendidikan Seks (sex education) adalah suatu pengetahuan yang mengajarkan mengenai segala sesuatu yang berhubungan dengan jenis kelamin. Pendidikan seks adalah pemberian informasi dan pembentukan sikap serta keyakinan tentang seks, identitas seksual, hubungan dan keintiman. Ini menyangkut anatomi seksual manusia, reproduksi, hubungan seksual, kesehatan reproduksi, hubungan emosional dan aspek lain dari perilaku seksual manusia. (Chomaria, 2012).

2. Waktu Tepat Memberikan Pendidikan Seks Anak Usia Dini

Dr. Rose Mini AP, M.Psi (dalam Mahluzatin, 2016) menyatakan bahwa pengetahuan mengenai seksualitas bagi anak wajib diberikan orangtua sedini mungkin, terutama saat anak masuk play group (usia 3-4 tahun). Tujuannya, agar mereka mengenal persamaan dan perbedaan antara pribadi seorang anak laki-laki dan perempuan, sehingga anak mampu mengenali diri mereka dengan baik.

3. Tujuan Pendidikan Seks Anak Usia Dini

a. Penanaman dan pengukuhan akhlak sejak dini kepada anak dalam menghadapi masalah seksual agar tidak mudah terjerumus pada pergaulan bebas.

b. Orangtua memberikan contoh berperilaku yang baik kepada anak-anak dalam keseharian.

c. Sebagai upaya preventif dalam kerangka moralitas agama untuk menghindari anak dari pergaulan bebas dan penyimpangan seksual.

d. Membekali anak dengan informasi yang benar dan tanggung jawab tentang seks agar terhindar informasi dari sumber-sumber yang tidak dapat dipertanggungjawabkan.

e. Memahami sejak dini tentang perbedaan mendasar antara anatomi pria dan wanita serta peran masing-masing gender dalam reproduksi manusia (El-Qudsy, 2012). 
4. Tahapan Perkembangan Seks Anak

Menurut Sigmund Frued (Asmoro, 2006) tahapan perkembangan seks pada anak mengalami empat tahapan psikoseksual yaitu:

a. Fase Oral ( 1 - 2 Tahun), yaitu fase seorang anak mendapatkan perasaan nikmat melalui mulutnya, yaitu ketika sedang menyusu dan menghisap puting payudara ibunya.

b. Fase Anal ( 2 - 4 Tahun) yaitu kenikmatan yang dirasakannya berubah dari mulut ke daerah anus dan sekitarnya (seperti saluran kencing). Kenikmatan seperti ini didapatkannya ketika anak menahan buang air besar maupun buang air kecil.

c. Fase Phalic (4 - 6 Tahun) yaitu anak akan merasakan kenikamatan tertentu ketika meraba atau menyentuh alat kelaminnya sendiri.

d. Fase Laten ( 6 - 12 Tahun) yaitu terbagi menjadi 2 bagian yaitu :1) Bagian Awal, seorang anak sudah tidak lagi memperhatikan kenikmatan yang penah dirasakan pada alat kelaminnya, bahkan cenderung seperti melupakan kejadian tersebut dan 2) Bagian Akhir, seorang anak mulai mnunjukkan kembali kenikmatan yang dirasakan melalui alat kelaminnya. Karena pada saat memasuki fase ini usia anak telah beranjak dewasa, dorongan seksual, perasaan cinta, dan ketertarikannya kepada lawan jenis mulai tumbuh. Jadi, perhatian anak beralih kepada alat kelaminnya adalah hal yang wajar.

5. Pendidikan Seks Tahap Awal

Beberapa hal yang perlu dibiasakan dan diajarkan kepada anak sejak mereka terlahir, sebagai upaya Pendidikan seks, antara lain :

a. Memberi nama anak sesuai dengan jenis kelaminnya

b. Memberi perlakuan sesuai dengan jenis kelamin anak

c. Mengenalkan bagian tubuh dan fungsinya

d. Mengajari cara membersihkan alat kelamin

e. Menanamkan rasa malu sedini mungkin

f. Memberi tahu bagian tubuh yang boleh atau tidak boleh disentuh orang lain

g. Memberi tahu jenis sentuhan yang pantas dan tidak pantas

h. Jangan biasakan disentuh lain jenis

i. Memisahkan tempat tidur anak 
j. Mengajari anak meminta izin pada waktu-waktu tertentu

k. Seleksi media yang dikonsumsi anak

\section{METODOLOGI PENELITIAN}

Jenis penelitian ini adalah penelitian kuantitatif deskriptif. Subjek penelitian berjumlah 50 orangtua (ibu) di PAUD Terpadu dengan menggunakan teknik probability sampling. Teknik pengumpulan dalam penelitian ini adalah menggunakan instrumen penelitian berupan kuesioner pengetahuan orangtua tentang pendidikan seks pada anak usia dini. Instrumen penelitian terlebih dahulu di uji validitas dan reliabilitas dan diperoleh hasil uji reliabilitas yaitu 0,897 dengan demikian kuesioner dinyatakan reliable dan analisis menggunakan statistik deskriptif. 
HASIL PENELITIAN

Tabel 1. Pengetahuan Orangtua Tentang Pendidikan Seks Pada Anak Usia Dini

\begin{tabular}{|c|c|c|}
\hline Indikator & Baik & Kurang \\
\hline Pengertian Pendidikan Seks & $68 \%$ & $32 \%$ \\
\hline $\begin{array}{l}\text { Waktu Tepat Memberikan Pendidikan Seks } \\
\text { AUD }\end{array}$ & $53 \%$ & $47 \%$ \\
\hline Tujuan Pendidikan Seks AUD & 87,7 & 12,3 \\
\hline Tahapan Perkembangan Seks Anak & $82 \%$ & $18 \%$ \\
\hline $\begin{array}{l}\text { Memberi Nama Anak Sesuai Jenis } \\
\text { Kelamin }\end{array}$ & $70 \%$ & $30 \%$ \\
\hline $\begin{array}{l}\text { Memberi Perlakuan Anak Sesuai dengan } \\
\text { Jenis Kelamin }\end{array}$ & $97 \%$ & $3 \%$ \\
\hline $\begin{array}{l}\text { Mengenalkan Bagian Tubuh dan } \\
\text { Fungsinya }\end{array}$ & $90 \%$ & $10 \%$ \\
\hline $\begin{array}{l}\text { Mengajari Cara Membersihkan Menjaga } \\
\text { Organ Reproduksi }\end{array}$ & $42 \%$ & $58 \%$ \\
\hline Menanamkan Rasa Malu Sedini Mungkin & $93 \%$ & $7 \%$ \\
\hline $\begin{array}{l}\text { Bagian Tubuh Yang Boleh dan Tidak } \\
\text { Boleh di Sentuh }\end{array}$ & $96 \%$ & $4 \%$ \\
\hline Sentuhan Pantas dan Tidak Pantas & $77 \%$ & $23 \%$ \\
\hline Jangan Biasakan di Sentuh Lain Jenis & $84 \%$ & $16 \%$ \\
\hline Pisahkan Tempat Tidur Anak & $88 \%$ & $12 \%$ \\
\hline $\begin{array}{l}\text { Mengajarkan Meminta Ijin Pada Waktu- } \\
\text { waktu Tertentu }\end{array}$ & $80 \%$ & $20 \%$ \\
\hline Seleksi Media yang di Konsumsi Anak & $100 \%$ & $0 \%$ \\
\hline
\end{tabular}




\section{PEMBAHASAN}

Pengetahuan orangtua di PAUD Terpadu tentang pendidikan seks pada anak usia dini adalah baik dengan persentase 79,5\% dengan demikian para orangtua di PAUD terpadu telah memiliki pengetahuan yang baik mengenai pendidikan seks pada anak usia dini. Dengan demikian diharapkan pengetahuan orangtua yang sudah ada dapat di bagikan kepada anak, orangtua dapat membimbing anak dengan baik agar terhindar dari pelecehan seksual, penyimpangan perilaku seksual dll .

Diperoleh 94\% orangtua yang berusia 18-40 tahun memiliki pengetahuan baik mengenai pendidikan seks, diperoleh $42 \%$ orangtua dengan latar pendidikan S1 memiliki pengetahuan yang baik mengenai pendidikan seks pada anak usia dini dan $45 \%$ dengan latar belakang pendidikan SMA. Hal tersebut membuktikan bahwa ketika seseorang berada pada fase perkembangan dewasa awal dan memiliki pendidikan yang memberikan pengalaman dan hubungan sosial yang lebih luas sehingga dapat menyebabkan terjadinya perubahan pemikiran dan perilaku (Hurlock.1990)

Terdapat $100 \%$ orangtua menjawab pentingnya mendampingi anak selama menonton televisi atau internet. Tidak dapat dipungkiri televisi dan internet turut menjadi penyebab cepatnya pengetahuan seks untuk anak, temasuk pada usia balita. Jika kebetulan anak melihat adegan "suka-sukaan", pacaran di film kartun atau di lingkungan sekolah, orangtua harus menjelaskan perilaku itu tidak sesuai. Orangtua harus dapat menyaring informasi dari televisi dan internet yang sampai ke anak, agar keingintahuan anak terhadap hal yang belum waktunya tidak terlalu cepat muncul (Boyke, 2016). Orangtua harus memberikan pengawasan terhadap tayangan yang layak dan tidak layak dilihat anak, mendampingi anak ketika mengakses internet, sehingga meminimalisir pengaruh buruk yang dapat terjadi pada anak.

Selain itu diperoleh $42 \%$ orangtua mengetahui pentingnya mengajari cara menjaga organ reproduksi, dengan demikian terdapat $58 \%$ orangtua berpendapat belum penting mengajari anak menjaga organ reproduksi sejak dini, hal ini dapat dipengaruhi oleh pandangan orangtua bahwa belum pantas anak-anak tahu mengenai hal itu. Anak usia 3 tahun adalah fase phallic yaitu fase dimana anak akan merasakan kenikmatan tertentu ketika menyentuh alat kelaminnya sendiri atau ketika bergesekkan dengan sesuatu. Anak mulai mengeksplore alat kelaminnya dan ingin tahu fungsi genitalnya, oleh karena itu pada fase ini peran orangtua sangat penting untuk melakukan edukasi 
seks pada anak menjaga organ reproduksinya dan ketika perilaku tersebut muncul orngtua dapat mengalihkan perhatian anak dengan kegiatan lain sehinnga jangka panjangnya dapat terhindar dari potensi pelecehan seksual dan penyimpangan perilaku seksual.

Orangtua di PAUD Terpadu mengetahui kebutuhan keamanan bagi anak sejak dini mengenai pendidikan seks, sehingga anak dapat membentengi dirinya dari perilaku yang tidak baik. Orangtua juga memiliki pengetahuan yang baik tentang bagian tubuh anak yang boleh disentuh dan tidak boleh disentuh oleh siapa pun seperti mulut, dada, kemaluan dan bagian bawah sekitar paha dan pantat. Sentuhan/menepuk pada bahu dan kepala anak boleh dilakukan oleh orang lain atau guru apabila anak mendapatkan sebuah prestasi saja. Dan sentuhan yang tidak pantas adalah ketika ada orang lain atau lawan jenis menyentuh bagian yang tertutup pakaian dalam anak. Anak-anak yang tidak biasa disentuh orang lain atau lawan jenis, akan menjaga jarak dan menolak apabila akan disentuh orang lain. Hal ini sebagai upaya protektif dimana anak akan lebih sukar dibujuk oleh orang lain.

Ketika anak sudah mulai masuk sekolah pemisahan tempat/kamar tidur anak dan orangtua perlu dilakukan agar anak tidak melihat aktifitas pibadi orangtua. Selain memisahkan tempat/kamar tidur anak dan orangtua pemisahan tempat/kamar tidur antara anak laki-laki dan perempuan juga perlu dilakukan agar mereka terhindar dari kontak fisik dan mencegah hal-hal yang tidak di inginkan. Dengan terpisahnya kamar tidur itu membuat anak terbiasa untuk meminta izin ketika memasuki kamar tidur orangtua maupun saudara yang lainnya. Dengan anak yang terbiasa selalu meminta izin, anak tidak akan mudah dibawa orang lain. Dan orangtua akan lebih mudah memantau anak. 


\section{KESIMPULAN DAN SARAN}

\section{Kesimpulan}

Berdasarkan hasil analisis data dapat disimpulkan bahwa pengetahuan orangtua tentang pendidikan seks pada anak usia dini di PAUD Terpadu masuk dalam kategori baik yaitu sebesar $79,5 \%$.

\section{Saran}

Berdasarkan hasil penelitia saran yang dapat diberikan kepada orangtua hendaknya lebih aktif mencari informasi mengenai pendekatan, metode atau cara memberikan pendidikan seks pada anak usia dini yang menyenangkan dan mudah dipahami anak. Saran bagi sekolah adalah melakukan pengawasan agar tidak terjadi pelecehan seksual dan penyimpangan perilaku seksual, selain itu guru dapat meningkatkan wawasan dengan aktif mengikuti kegiatan seminar atau workshop yang berkaitan dengan pendidikan seks. Saran bagi peneliti selanjutnya, dapat melakukan pelatihan bagi orangtua di daerah yang menganggap "tabu" pendidikan seks. 


\section{DAFTAR PUSTAKA}

Ajen, Dianawati. 2003. Pendidikan Seks Untuk Remaja. Kawan Pustaka. Jakarta

Anggraeni, Legina. 2014. Faktor-Faktor Yang Berhubungan Dengan Tingkat Pengetahuan Orangtua Terhadap Pendidikan Seksual Pada Anak Usia Dini di Sekolah Dasar Katika VIII-5 Jakarta Selatan. Jurnal Fakultas Kesehatan Masyarakat Universitas Indonesia. Vol 1, No 2 (Desember 2017)

Asmoro, Guno. 2006. Sex Education for Kids. Kreasi Wacana Yogyakarta

Chomaria, Nurul. 2014. Pendidikan Seks Untuk Anak. Aqwam Medika

Dian Nugraha, Boyke \& dkk 2016. Adik Bayi Datang Dari Mana? A-Z Pendidikan Seks Usia Dini. PT Mizan Publika Jakarta Selatan

Dwi Rini Kurnia Fitri. 2016. Parent's Knowledge About Sex Education in Early Childhhood to Prevent Secxual Abuse. Proceeding International Seminar on Education. IAIN Batusangkar Indonesia. (ecampus.iainbatusangkar.ac.id/ojs/index.php/proceedings/article/viewFile/633/ 625.)

Dyah Siwi Hety. 2017. Pengetahuan Orangtua Tentang Pendidikan Seks Dini Pada Anak Usia Pra Sekolah (3-6 tahun) di TK Tunas Jaya Bangsal Mojokerto. Jurnal Hospital Majapahit. Vol 9. No 2 (http://ejurnalp2m.poltekkesmajapahit.ac.id/index.php/HM/article/view/157)

El-Qudsy, Hasan. 2012. Ketika Anak Bertanya Tentang Seks. Panduan Islami Bagi Orangtua Mendampingi Anak Tumbuh Menjadi Dewasa. Tinta Media. Solo

Eswinda Mahluzatin. 2016. Persepsi Orangtua Tentang Pendidikan Seks AUD. UM Sunan Ampel. Surabaya. (http://digilib.uinsby.ac.id/13023/)

Notoatmodjo, Soekidjo. 2010. Promosi Kesehatan Teori dan Aplikasi. Rineka Cipta. Jakarta

Sabrina Salsabila. 2017. Gambaran Tingkat Pengetahuan Orangtua Tentang Program Underwear Rules dalam Pencegahan Kekerasan Seksual Pada Anak Usia Pra Sekolah. UIN Syarif Hidayatullah Jakarta

Sani B. Hermawan. 2010. Pentingnya Pendidikan Seks pada Anak, http://www.waspada.co.id

Santrock, J.W. (2012). Perkembangan Masa Hidup (Edisi Ketigabelas) (Jilid I). (Terjemahan Benedictine Widyasinta). New York City: McGraw-Hill. (Buku asli diterbitkan tahun 1997).

Sarwono, S. W. (2008). Psikologi Remaja. Jakarta: Rajagrafindo Persada

Suciemilia. (2015). Identifikasi Peran Orangtua dalam Memberikan Pendidikan Seksual pada Anak Tunagrahita Di SLBN 1 Bantul Yogyakarta. (http://lib.unisayogya.ac.id)

Sugiyono. 2014. Metode Penelitian Kuantitatif, Kualitatif dan $R$ \& D. Alfabeta. Bandung

Wiyani \& Barnawi, Novan Ardy. 2014. Format Paud. Aruzz Media. Jogjakarta 